\title{
Intraoperative Anesthesia-Related Mortality: A 10- Year Survey in a Tertiary Teaching Hospital
}

\author{
Intraoperatif Anestezi İlişkili Mortalite: Bir Yükseköğretim Hastanesinde 10 \\ Yıllık Bir Araştırma
}

\author{
Mehmet Selim Çömez ${ }^{1^{\star}}$, Hilmi Demirkıran ${ }^{2}$ \\ ${ }^{1}$ Hatay Mustafa Kemal Üniversitesi, Anesteziyoloji ve Reanimasyon Ana Bilim Dali, Hatay \\ ${ }^{2} V$ an Yüzüncü Yul Üniversitesi, Anesteziyoloji ve Reanimasyon Ana Bilim Dal, Van
}

\section{ÖZET}

Amaç: Bu çalışmada Türkiye'de bir eğitim ve araştırma hastanesinde son 10 y1lda anestezi ilișkili mortalite ve intraoperatif mortalite (IOM) insidanslar1 ile birlikte ilişkili risk faktörlerinin belirlenmesi amaçlandı. Materyal ve Metod: 2010-2019 yıllarını içeren operasyonlar retrospektif olarak tarandi. Son 10 yilda anestezi uygulanan 351.930 hastadan 87 nin ex olduğu belirlendi. Ex olan her hasta hasta/durum ilişsili, cerrahi işlem ilişkili ya da anestezi ilişkili mortalite grubundan birine toplandı. Hasta özellikleri yaş, cinsiyet, ASA skoru ve komorbiditeler olarak belirlendi. Cerrahi işlemler minör/intermediate, major ve major kompleks olarak sınıflandırıldı. Anestezi tipi, cerrahi işlem süresi, vazopressor ihtiyac1, invazif monitorizasyon tipi belirlendi.

Bulgular: Intraoperatif mortalitenin genel insidans1 10.000 de 2,47 idi. Anestezi ilişkili mortalite insidansı 10.000 de 0,28 idi. IOM grubundaki hastalar mesai dış1 çalışma, cerrahi aciliyet, uzun cerrahi süresi, yüksek komorbidite oranı, yüksek ASA skoru, yüksek komplekli cerrahilere, vp kullanımına, invazif monitorizasyon kullanımına sahipti. Çok yönlü lojistik regresyon modeli cerrahi aciliyeti (p:0,000), vp kullanımı (p:0,002) ve invazif monitörizasyonu (p:0,000) IOM nin bağımsız belirleyicileri olarak tanımladı. Anestezi ilişkili mortalite gelişen hastalarda ise yüksek kompleksli cerrahiler (p: 0.007), cerrahi aciliyet ( $\mathrm{p}: 0.000$ ), vp kullanımı (p: 0.002) ve invazif monitorizasyon (0.000) potansiyel olarak ilişkili özelliklerdi.

Sonuç: Mortalite oranları anestezi ilişkili 10.000 de 0.28 , genel IOM 10.000 de 2,47 idi. Anestezi ilişkili mortalitenin havayolu yönetimi veya ilaç verilmesiyle ilişkili olması önleyici tedbirlerin gelişimi için önemlidir. Kötü ASA skoruna bağlı yüksek fatalite oranını azaltmada primer önleme kilit rol oynayabilir. Bu bulgular yüksek riskli ve acil hastalarda trbbi perioperatif uygulamalar1 geliştirme ihtiyacını göstermektedir.

Anahtar Kelimeler: Anestezi, mortalite, insidans, ASA skoru

\begin{abstract}
Purpose: This study aimed to determine anesthesiarelated mortality and intraoperative mortality (IOM) incidences and the associated risk factors. Material and Methods: The operations between the years of 2010-2019 were retrospectively reviewed. It was found that 87 of 351,930 patients who were anesthetized in the last 10 years died. Each patient who died was recruited into one of the patient/condition-related, surgical-related, or anesthesia-related mortality groups. Patient characteristics were determined as age, gender, ASA PS score, and comorbidities. Surgical procedures were classified as minor/intermediate, major, and major complex. Anesthesia type was recorded. Operative time, the requirement for vasopressor and the invasive monitoring were determined.
\end{abstract}

Results: The incidence of IOM and anesthesia-related mortality were 2.47 and 0.28 per 10,000 patients, respectively. The IOM group had a higher rate of out-ofhours work, surgical emergency, prolonged operative time, high comorbidity rate, high ASA PS score, major complex surgeries, use of VP, and invasive monitoring. Surgical emergency (p: 0.000), use of VP (p: 0.002), and invasive monitoring (p: 0.000$)$ were independent determinants of IOM. Major complex surgeries ( $\mathrm{p}$ : 0.007), surgical emergency (p: 0.000), use of VP (p: 0.002 ), and invasive monitoring (0.000) were potentially associated factors in anesthesia-related mortality. Conclusion: The incidence of IOM and anesthesia-related mortality were 2.47 and 0.28 per 10,000 patients, respectively. The fact that anesthesia-related mortality was associated with drug administration is important for the development of preventive measures. Primary prevention may play a key role in reducing the high fatality. These results indicate the need for improving medical perioperative practices in high-risk and emergency patients.

Key Words: Anesthesia, mortality, incidence, ASA PS

*Sorumlu Yazar: Mehmet Selim Çömez, Department of Anesthesiology and Reanimation, Tayfur Ata Sökmen Faculty of Medicine, Hatay Mustafa Kemal University, Hatay, Turkey

E-mail: drmcomez313@gmail.com,phone: +090(506)5090953

ORCID ID: Mehmet Selim Çömez: 0000-0003-0821-5148, Hilmi Demirkıran: 0000-0001-8116-3933

Geliş Tarihi: 26.11.2020, Kabul Tarihi: 04.02.2021 


\section{Introduction}

Perioperative cardiac arrest and mortality are the most important and feared complications of surgical operations (1) Not only anesthesia-related events, but also surgical technique and patient / condition-related events cause intraoperative mortality (IOM) (2). Most of IOM is unrelated to anesthesia $(2,3)$.

Anesthesia has the potential to induce physiological changes that can lead to morbidity and mortality and is widely considered a high-risk activity. However, many researchers have reported that anesthesia-related mortality has decreased for the last two decades. This reduction has been attributed to several safety developments, including improved monitoring techniques, the development and extensive use of practice guidelines, and other systematic approaches to reduce errors (4). Thus, the evaluation of intraoperative mortality enables us to know the quality of anesthesia management.

Anesthesia-related mortality is investigated in some countries (USA, France). Numerous publications on perioperative cardiac arrest have shown significant differences between countries. This heterogeneity stems from the definition of anesthesia-related mortality, age populations, surgical populations, time periods, and studies in different developing countries $(5,6)$. The evaluation of intraoperative mortality provides information on the quality of anesthesia management, enables preventive measures to be taken, and guides future research $(1-3,7)$. To our latest knowledge, the number of studies on anesthesia-related mortality in Turkey is limited.

This study aimed to determine anesthesia-related mortality and IOM incidences of a training and research hospital in Turkey in the last 10 years and the associated risk factors.

\section{Materials and Methods}

After obtaining the approval of the Non-Invasive Clinical Research Ethics Committee of Hatay Mustafa Kemal University (HMKU) numbered 27.02.2020/10, the operations of all clinics that were performed in the operating room of HMKU Research Hospital between the years of 2010 and 2019 were retrospectively reviewed. Cardiac, noncardiac and obstetric surgeries in all age groups were included in the study. The dead fetus in cesarean operation and the patients who came to the operating room with cardiopulmonary resuscitation and who did not undergo anesthesia and surgery were excluded from the study. Retrospective results were obtained from the Hospital Information Management System and the archives of the Department of Anesthesiology. HMKU Research Hospital is a hospital with 503 beds, 15 operating rooms including all surgical specialties, and 64 ICU beds. Anesthetic care is carried out by 7 anesthesiologist lecturers, 16 residents, and 43 anesthesia technicians. For the objective of the present study, the intraoperative period was defined as the time between the patient's arrival to the operating room and leaving the recovery room. Since patients who received anesthesia but did not die were required to determine the risk factors for mortality, for each patient who died, patients operated just before and after them in the same operating room on the same day were selected, if there were no patients, patients operated in the previous and next days were selected. Thus, 2 other patients who did not die were selected for each patient who died.

Based on the available literature, each patient who died was recruited into one of the patient/condition-related (P/C-IOM), surgical procedure-related (S-IOM), totally anesthesiarelated (TA-IOM), or partially anesthesia-related (PA-IOM) mortality groups. TA-IOM was defined as patients who developed arrest immediately after administering an anesthetic drug to a stable patient or who developed arrest due to all obvious adverse events in airway management. PA-IOM was defined as arrests that occurred in unstable patients (such as hemorrhagic shock) after the administration of an anesthetic induction agent. SIOM was defined as mortality due to technical surgical problems alone or majorly. P/C-IOM was defined as mortality related to the patient's disease or condition. Patient characteristics were determined as age, gender, ASA PS score, and comorbidities. Surgical procedures were classified as minor/intermediate, major, and major complex depending on the severity of physiological stress, estimated blood loss, invasiveness, and operative time. Minor and intermediate surgical procedures included varicose vein removal, laparoscopic cholecystectomy, laparoscopic appendectomy, hemorrhoidectomy, thyroidectomy, transurethral prostate surgery, parathyroidectomy, and carpal tunnel. Major surgical procedures included craniotomy, colectomy, nephrectomy, bariatric surgery, and splenectomy. Major complex surgical procedures included coronary artery bypass grafting surgery, ruptured aortic aneurysm, radical cystoprostatectomy, mitral valve replacement. 
Table 1. Classification, number and incidences of IOM

\begin{tabular}{lccccccccc}
\hline & & $\begin{array}{c}\text { Number } \\
\text { of }\end{array}$ & $\begin{array}{c}\text { Anesthesia- } \\
\text { related } \\
\text { Total }\end{array}$ & $\begin{array}{c}\text { Surgery- } \\
\text { associated } \\
\text { IOM }\end{array}$ & $\begin{array}{c}\text { Patient } / \\
\text { condition } \\
\text { related } \\
\text { IOM }\end{array}$ & $\begin{array}{c}\text { T-IOM } \\
\text { incidence }\end{array}$ & $\begin{array}{c}\text { A-IOM } \\
\text { incidence }\end{array}$ & $\begin{array}{c}\text { S-IOM } \\
\text { incidence }\end{array}$ & $\begin{array}{c}\text { P/C- } \\
\text { incidence }\end{array}$ \\
\hline 2010 & 6 & 15153 & 1 & 0 & 5 & 3,95 & 0,65 & 0 & 3,29 \\
2011 & 2 & 19732 & 0 & 1 & 1 & 1,01 & 0 & 0,5 & 0,5 \\
2012 & 13 & 25941 & 1 & 2 & 10 & 5,01 & 0,38 & 0,77 & 3,85 \\
2013 & 11 & 22848 & 1 & 2 & 8 & 4,81 & 0,43 & 0,87 & 3,5 \\
2014 & 9 & 37303 & 0 & 2 & 7 & 2,41 & 0 & 0,53 & 1,87 \\
2015 & 11 & 40538 & 2 & 2 & 7 & 2,71 & 0,49 & 0,49 & 1,72 \\
2016 & 7 & 38772 & 1 & 2 & 4 & 1,8 & 0,25 & 0,51 & 0,98 \\
2017 & 6 & 43149 & 0 & 3 & 3 & 1,39 & 0 & 0,69 & 0,69 \\
2018 & 12 & 57535 & 3 & 4 & 5 & 2,08 & 0,52 & 0,69 & 0,86 \\
2019 & 10 & 50959 & 1 & 4 & 5 & 1,96 & 0,19 & 0,78 & 0,98 \\
Total & 87 & 351930 & 10 & 22 & 55 & $2,47 *$ & $0,28 *$ & $0,62 *$ & $1,56 *$ \\
\hline
\end{tabular}

IOM: Intraoperative mortality; T-IOM: Total IOM; A-IOM: Anesthesia-related IOM; S-IOM: Surgery-related IOM; P/C-IOM: Patient/condition-related IOM;

* 10-year average incidence

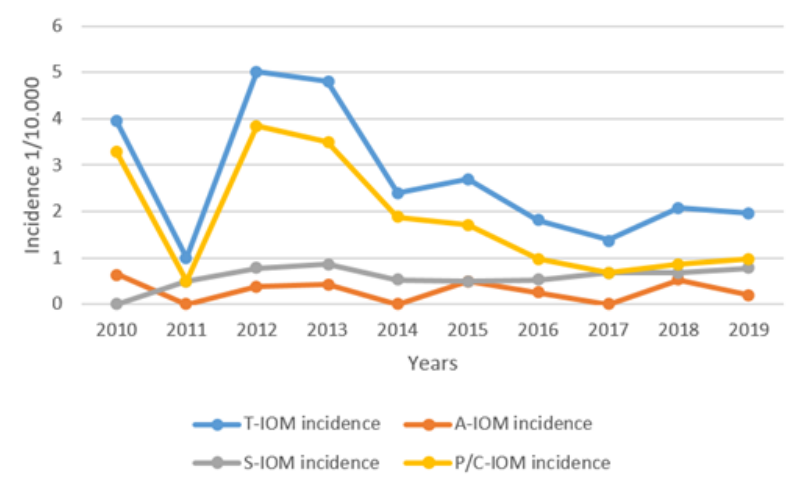

Fig.1. Annual incidences of IOM T-IOM: Total IOM; A-IOM: Anesthesia-related IOM; S-IOM: Surgery-related IOM; P/C-IOM: Patient/condition-related IOM

Anesthesia type was recorded as general, regional, sedoanalgesia, and monitored anesthesia care. In addition, operative time (min), hemodynamic stability, the requirement for vasopressor (VP), invasive monitoring type were determined. Primary ECG rhythm (Asystole, VF, PEA), time of cardiac arrest (induction, maintenance, awakening, recovery room), number of cardiac arrests during the same event, cardiac arrest time associated with standard working hours (08.00$16.00,16.00-08.00$, weekend)) were recorded to determine the etiology and time of the arrest.

Descriptive statistics for the continuous variables were presented as mean and standard deviation while categorical variables as count and percent. Student $t$ test was performed to compare IOM and Non-IOM groups for the continuous variables. Pearson correlation analysis was carried out to examine linear relationships among these variables. In addition, Pearson Chi- square test was used to determine relationships between categorical variables. Multiple logistic regression was performed to determine effective variables on the mortality. Statistical significance level was considered as 5\% and SPSS (ver: 23) statistical program was used for all statistical computations.

\section{Results}

Incidence of Mortality: During the 10-year course of the study, 351,930 patients were anesthetized at HMKU Research Hospital. A total of 87 patients died. The overall incidence of intraoperative mortality was 2.47 per 10,000 patients (Table 1). Ten patients who developed anesthesia-related mortality were identified (Table 2). One of them was neuraxial anesthesia-related, nine of them were partially anesthesia-related. The incidence of anesthesia-related mortality was 0.28 per 10,000 patients. The changes in incidence by years are shown in Figure 1. Of the patients who died, 36 were Syrian (refugee), 51 were citizens of the Republic of Turkey.

Analysis of mortality-related factors: The mean age of 87 patients who intraoperatively died was 47.16 years. Of these patients, 4 were newborns. One of them was operated for diaphragmatic hernia, one for omphalocele, one for atrial septal defect + patent ductus arteriosus (PDA), and the other for firearm injury (FAI) (craniotomy). Seven patients, excluding newborns, were under 18 years of age. A 1.5-year-old patient underwent laparotomy (Hypovolemic shock, Hirschprung disease, Electrolyte disorder). A 4-year-old patient 
Table 2. Intraoperative mortality related to anesthesia

\begin{tabular}{|c|c|c|c|c|c|c|}
\hline $\begin{array}{l}\text { Patient } \mathrm{n} \\
\text { (year) }\end{array}$ & $\begin{array}{l}\text { Age } \\
\text { (years) }\end{array}$ & $\begin{array}{l}\text { ASA PS } \\
\text { class }\end{array}$ & $\begin{array}{l}\text { Arrest } \\
\text { type }\end{array}$ & $\begin{array}{l}\text { Resuscitation } \\
\text { time (minutes) }\end{array}$ & Time of arrest & Probable cause of mortality \\
\hline $1(2010)$ & 92 & $3 \mathrm{E}$ & VF & 65 & Post-surgery & $\begin{array}{l}\text { Hypovolemic shock, Heart } \\
\text { failure }\end{array}$ \\
\hline $2(2012)$ & 0 & $3 \mathrm{E}$ & VF & 45 & Induction & $\begin{array}{c}\text { Neonatal respiratory failure, } \\
\text { Diaphragmatic hernia }\end{array}$ \\
\hline $3(2013)$ & 63 & $4 \mathrm{E}$ & VF & 60 & Induction & $\begin{array}{l}\text { Hypovolemic shock due to } \\
\text { massive bleeding }\end{array}$ \\
\hline $4(2015)$ & 42 & $4 \mathrm{E}$ & Asistol & 50 & Induction & $\begin{array}{c}\text { Cardiogenic shock following } \\
\text { induction }\end{array}$ \\
\hline $5(2015)$ & 29 & $3 \mathrm{E}$ & VF & 45 & Induction & $\begin{array}{l}\text { Hypovolemik shock, septic } \\
\text { shock }\end{array}$ \\
\hline $6(2016)$ & 79 & $4 \mathrm{E}$ & Asistol & 45 & Induction & $\begin{array}{l}\text { Hypovolemic shock, Aort } \\
\text { dissection }\end{array}$ \\
\hline 7 (2018) & 20 & $3 \mathrm{E}$ & PEA & 45 & Induction & $\begin{array}{l}\text { Hypovolemic shock due to } \\
\text { massive bleeding }\end{array}$ \\
\hline $8(2018)$ & 89 & $4 \mathrm{E}$ & Asistol & 45 & Post-NAA & $\begin{array}{c}\text { Hypovolemic shock after } \\
\text { spinal anesthesia } *\end{array}$ \\
\hline $9(2018)$ & 31 & $3 \mathrm{E}$ & PEA & 45 & Induction & $\begin{array}{l}\text { Hypovolemic shock due to } \\
\text { massive bleeding, gunshut } \\
\text { injury, Post-CPR }\end{array}$ \\
\hline $10(2019)$ & 1,5 & $3 \mathrm{E}$ & Asistol & 60 & Induction & $\begin{array}{l}\text { Hypovolemic shock, } \\
\text { electrolyte imbalance, } \\
\text { hirschsprung disease }\end{array}$ \\
\hline
\end{tabular}

ASA PS - American Society of Anesthesiology physical status; VF: Ventricular fibrilation; PEA: Pulseless electrical activity; NAA: Neuroaxial anesthesia; CPR: Cardiopulmonary resuscitation

* Totally-anesthesia related

underwent PDA closure with thoracotomy (Aortic Stenosis, Aortic Insufficiency, PDA). A 7-yearold patient from the Syrian civil war (FAI, Multiple Trauma) underwent craniotomy. An 8year-old patient who came from the Syrian civil war underwent thoracotomy and laparotomy (FAI, Post CPR, Multiple Trauma). A 9-year-old patient underwent limb lengthening implantation (Motor Mental Retardation, musculoskeletal deformity). A 12 -year-old patient underwent laparotomy (acute abdomen, sepsis). A 12-year-old patient underwent arterial and venous repair (Arteriovenous malformation). Twenty patients, 17 of whom were from the Syrian civil war, were operated on for firearm injury and multiple trauma. Thirty-three patients underwent major complex cardiovascular surgery (CVS). Seven patients were operated on by obstetric surgery. Of the patients, $24.1 \%$ were elective and $75.9 \%$ were emergency cases.

Compared to the patients in the non-IOM group, the patients in the IOM group had higher rate of out-of-hours work $(41.4 \%$ vs. $8.7 \%$; p: 0.001$)$, higher rate of surgical emergency $(75.9 \%$ vs. 24.1\%; p: 0.001), longer operative time (p: 0.001), higher rate of comorbidity $(97.7 \%$ vs. $49.7 \%$; p: 0.001), higher ASA PS score ( $97.7 \%$ vs. $32.4 \%$; p: 0.001 ), higher rate of complicated surgery (p: $0.001)$, use of VP $(89.7 \%$ vs. 20.3 ; p: 0.001$)$, and higher invasive monitoring use $(98.9 \%$ vs $33.1 \%$; p: 0.001). There was no difference between the groups in terms of age and gender (Table 3). The multiple logistic regression model defined surgical emergency ( $p$ : 0.001), use of VP (p: 0.002), and invasive monitoring (p: 0.001) as independent determinants of IOM (Table 4).

Analysis of factors associated with the risk of anesthesia-related IOM: Major complex surgeries (p: 0.007), surgical emergency (p: 0.001), use of VP (p: 0.002), and invasive monitoring $(0.001)$ were the potentially associated factors in patients who developed anesthesia-related mortality (A-IOM) (Table 5).

\section{Discussion}

Incidence of intraoperative mortality: It is difficult to compare the IOM rates in our study with the results of previous studies, as there are 
Table 3. Characteristics of intraopetative mortality ( $\mathrm{IOM}$ ) cases and those in the non-IOM comparison group

\begin{tabular}{|c|c|c|c|}
\hline & $\begin{array}{l}\text { IOM cases } \\
\quad(n=87) \\
\text { Count or } n(\%)\end{array}$ & $\begin{array}{l}\text { Non-IOM cases } \\
\qquad(n=173) \\
\text { Count or } n(\%)\end{array}$ & $\mathrm{P}$ \\
\hline $\begin{array}{l}\text { Nationality } \\
\text { Syria (refugee) } \\
\text { Türkiye }\end{array}$ & $\begin{array}{l}37(42,5 \%) \\
50(57,5 \%)\end{array}$ & $\begin{array}{c}32(20,5 \%) \\
124(79,5 \%)\end{array}$ & $0,001 *$ \\
\hline $\mathrm{Age}^{* *}$ & $47,16(24,630)$ & $43,61(19,533)$ & 0,210 \\
\hline $\begin{array}{l}\text { Gender } \\
\text { Female } \\
\text { Male }\end{array}$ & $\begin{array}{l}38(43,7 \%) \\
49(56,3 \%)\end{array}$ & $\begin{array}{l}78(45,1 \%) \\
95(54,9 \%)\end{array}$ & 0,829 \\
\hline $\begin{array}{l}\text { Working hours } \\
\text { Standard } \\
\text { Non-standard }\end{array}$ & $\begin{array}{l}51(58,6 \%) \\
36(41,4 \%)\end{array}$ & $\begin{array}{cc}157(91,3 \%) & 15 \\
(8,7 \%) & \end{array}$ & $0,001 *$ \\
\hline $\begin{array}{l}\text { ASA PS class } \\
\text { ASA } 1,2 \\
\text { ASA } 3,4,5\end{array}$ & $\begin{array}{c}2(2,3 \%) \\
85(97,7 \%)\end{array}$ & $\begin{array}{c}117(67,6 \%) \\
56(32,4 \%)\end{array}$ & $0,001 *$ \\
\hline $\begin{array}{l}\text { Comorbidity } \\
\text { Yes } \\
\text { No }\end{array}$ & $\begin{array}{c}85(97,7 \%) \\
2(2,3 \%)\end{array}$ & $\begin{array}{l}86(49,7 \%) \\
87(50,3 \%)\end{array}$ & $0,001 *$ \\
\hline $\begin{array}{l}\text { Urgency } \\
\text { Elective } \\
\text { Urgent }\end{array}$ & $\begin{array}{l}21(24,1 \%) \\
66(75,9 \%)\end{array}$ & $\begin{array}{l}129(74,6 \%) \\
44(25,4 \%)\end{array}$ & $0,001 *$ \\
\hline $\begin{array}{l}\text { Type of surgery } \\
\text { Minor/intermediate } \\
\text { Major } \\
\text { Major complex }\end{array}$ & $\begin{array}{l}10(11,5 \%) \\
45(51,7 \%) \\
32(36,8 \%)\end{array}$ & $\begin{array}{l}73(42,2 \%) \\
60(34,7 \%) \\
40(23,1 \%)\end{array}$ & $0,001 *$ \\
\hline $\begin{array}{l}\text { Type of anesthesia } \\
\text { General } \\
\text { Regional } \\
\text { Sedoanalgesia }\end{array}$ & $\begin{array}{c}83(95,4 \%) \\
3(3,4 \%) \\
1(1,1 \%)\end{array}$ & $\begin{array}{l}131(75,7 \%) \\
27(15,6 \%) \\
15(8,7 \%)\end{array}$ & $0,001 *$ \\
\hline Duration of surgery** & $157,92(131,502)$ & $103,96(72,361)$ & $0,001 *$ \\
\hline $\begin{array}{l}\text { Use of vasopressors } \\
\text { Yes } \\
\text { No }\end{array}$ & $\begin{array}{c}78(89,7 \%) \\
9(10,3 \%)\end{array}$ & $\begin{array}{c}35(20,3 \%) \\
137(79,7 \%)\end{array}$ & $0,001 *$ \\
\hline $\begin{array}{l}\text { Use of arterial line and CVP monitor } \\
\text { Yes } \\
\text { No }\end{array}$ & $\begin{array}{c}86(98,9 \%) \\
1(1,1 \%)\end{array}$ & $\begin{array}{c}57(33,1 \%) \\
115(66,9 \%)\end{array}$ & $0,001 *$ \\
\hline
\end{tabular}

n: number; ASA PS: American Society of Anesthesiology physical status; CVP: central venous pressure;

$\square$ p values $<0.05$;

**Mean (Standard Deviation)

significant differences between studies (3) in terms of method, surgical procedures, time periods, and patient population. Despite the differences in methodology, studies $(2,8,9)$ have shown mortality rates between 2.4 and 3.5 per 10,000 patients $(10,11)$. Throughout the 10 -year period, 351,930 patients received anesthesia in all surgical clinics of our institution. Over the 10 -year period, the IOM rate was 2.47 per 10,000 patients. The AIOM (TA-IOM + PA-IOM) rate was 0.28 per 10,000 patients (Table 1). These rates included refugee patients, CVS cases, and obstetric cases. In the study by Sobreira-Fernandes D et al. (2) the anesthesia-related mortality rate was 0.65 per 10,000 patients, and in their study in France, Lienhart et al. (12) found that it was 0.54 per 10,000 patients nationwide. There was only one TA-IOM over 10 years and its incidence was 0.028 per 10,000 patients. In the present study, the annual analysis of IOM showed an increase in the incidence due to the cases from the Syrian civil war in 2012-15 (Figure 1). 
Çömez ve Demirkıran / Intraoperative Anesthesia-Related Mortality

Table 4. Multivariate analysis of the characteristics potentially associated with mortality

\begin{tabular}{cccccccc}
\hline & B & S.E. & Wald & P & OR & \multicolumn{2}{c}{ 95\% C.I.for OR } \\
\cline { 7 - 9 } & & & & & & Lower & Upper \\
\hline Urgency & $-2,443$ &, 529 & 21,331 & $0,000^{*}$ &, 087 &, 031 &, 245 \\
Use of vasopressors & $-2,042$ &, 667 & 9,358 & $0,002^{*}$ &, 130 &, 035 &, 480 \\
Invasive monitorizasyon & $-4,901$ & 1,325 & 13,677 & $0,000^{*}$ &, 007 &, 001 &, 100 \\
\hline
\end{tabular}

Table 5. Multivariate analysis of the characteristics potentially associated with anesthesia-related mortality

\begin{tabular}{ccccccccc}
\hline & B & S.E. & Wald & p & OR & \multicolumn{2}{c}{ 95\% C.I.for EXP(B) } \\
\cline { 6 - 9 } & & & & & & Lower & Upper \\
\hline $\begin{array}{c}\text { Type of surgery } \\
\text { (major complex) }\end{array}$ & $-2,753$ & 1,013 & 7,393 & $0,007^{*}$ &, 064 &, 009 &, 464 \\
$\quad$ Urgency & $-2,443$ &, 529 & 21,331 & $0,000^{*}$ &, 087 &, 031 &, 245 \\
Use of vasopressors & 2,042 &, 667 & 9,358 & $0,002^{*}$ & 7,703 & 2,082 & 28,492 \\
$\quad \begin{array}{c}\text { Invasive } \\
\text { monitorization }\end{array}$ & 4,901 & 1,325 & 13,677 & $0,000^{*}$ & 134,393 & 10,009 & 1804,450 \\
\hline
\end{tabular}

OR - odds ratio;

CI - confidence interval;

$\square$ p values $<0.05$.

The incidence of P/C-IOM was higher than the incidence of anesthesia- and surgery-related mortality (Table 1, Figure 1). We can appreciate the significant contribution of the patient's illness to their outcome following perioperative cardiac arrest. This highlights the importance of adequate preoperative preparation in the process in which the anesthesiologist should have a leading role. Arbous et al. (7) mentioned that factors contributing to coma or death determined preventive measures to improve both quality and safety.

Factors associated with the risk of anesthesiarelated mortality: The characteristics of the patients who developed anesthesia-related mortality are shown in Table 2. IOM was not correlated with age and gender. There were no ASA 1, 2, or elective patients in A-IOM. All patients were ASA $3 \mathrm{E}$ or $4 \mathrm{E}$. The potentially associated factors with A-IOM were major complex surgeries, surgical emergency, use of VP, and invasive monitoring (Table 5). The emergency of the surgery is a well-established preoperative predictive factor for A-IOM, as shown in our study and other studies (3, 13). In emergency surgeries, mortality risk depends on many factors such as the impossibility of adequate evaluation and preoperative patient preparation-optimization. Sobreira-Fernandes D et al.(2) found that anesthesia-related mortality was associated with medication with $44 \%$ and airway/ventilation with $44 \%$. Sprung et al (14) reported these rates as
$54.2 \%$ and $45.8 \%$, and Newland et al.(5) reported these rates as $40 \%$ and $20 \%$. In our study, there were no respiratory causes for A-IOM. In medication-related mortality, 8 patients had a relative overdose for the patient or an abnormal response to a standard dose. In a study designed to evaluate perioperative medication errors and adverse drug events, inappropriate medication doses were reported as the most common type of error. The most common drugs associated with this were reported as propofol, phenylephrine, and fentanyl (15). Sprung et al (14) reported that $37.5 \%$ of cardiac arrests developed due to the use of NMB agents. In our study, 8 of the PA-IOM developed during induction and due to relative overdose in unstable patients. Most of the PAIOMs were associated with cardiovascular dysfunction, in line with the study of SobreiraFernandes D et al. (2). It has been shown that targeted fluid therapy reduces postoperative morbidity and mortality in patients with limited cardiovascular reserve (16). Arbous et al. (7) discovered that $52 \%$ of $\mathrm{A}-\mathrm{IOM}$ were associated with inadequate cardiovascular management and that the most critical period was induction and maintenance. In our study, we determined that 1 patient died after neuraxial anesthesia (NAA), 1 patient died after surgery, and the other 8 patients died during induction. However, no patient died during the maintenance period. One patient died after the administration of NAA. In the loss of sympathetic system-mediated vasoconstriction 
after NAA, vascular resistance may be decreased and sympathetic system-mediated loss of cardiac tone can reduce both heart rate and stroke volume. Vasodilation causes peripheral blood to pool and a decrease in the end-diastolic volume (17).

Factors associated with the risk of intraoperative mortality: Factors associated with the risk of intraoperative mortality: Compared to patients in the non-IOM group, the patients in the IOM group (Table 3) had higher out-of-hours work, higher surgical emergency, longer operative time, higher comorbidity rate, higher ASA PS score, major complex surgery, use of VP, higher use of invasive monitoring. Sobreira-Fernandes D et al. (2), on the other hand, found advanced age, high ASA PS score, cardiac diseases, surgery type, and use of VP. In addition, high ASA PS scores, high comorbid diseases, and use of VP were determined as predictive factors. Newland et al. (5) also determined ASA PS, emergency surgery, thoracic and spinal surgery as predictive factors. The predictive factors in our study were a surgical emergency, use of VP, and invasive monitoring (Table 4).

The most important limitation of this study is that it represents only a tertiary research hospital. Another limitation is the lack of follow-up records of the cases from the postoperative period to discharge. Despite the limitations of this study, to our latest knowledge, it is the first retrospective observational study including all age groups and all surgical clinics in Turkey over a 10 -year period. Multicenter and standardized studies can contribute to the development of universally acceptable strategies.

Conclusion: The majority of IOMs were caused by anesthesia-unrelated factors. The incidence of anesthesia-related mortality was 0.28 per 10,000 patients and the overall IOM incidence was 2.47 per 10,000 patients. There were no ASA 1,2, and elective patients in any anesthesia-related mortality. All patients were ASA 3E and 4E. The fact that anesthesia-related mortality was associated with airway management or drug administration is important for the development of preventive measures. Primary prevention may play a key role in reducing the high fatality rate in surgical patients due to poor ASA PS scores. These results indicate the need for improving medical perioperative practices in high-risk and emergency patients.

\section{References}

1. Turgay Yıldırım Ö, Turgay A, Aksoy Ö, Laflı Tunay D. Perioperatif Kardiyak Arrest ve Mortalite. Çukurova Anestezi ve Cerrahi Bilimler Dergisi 2019; 2(1): 5-10.

2. Sobreira-Fernandes D, Teixeira L, Lemos TS, Costa L, Pereira M, Costa AC, et al. Perioperative cardiac arrests-A subanalysis of the anesthesiarelated cardiac arrests and associated mortality. Journal of clinical anesthesia 2018; 50: 78-90.

3. Nunes JC, Braz JR, Oliveira TS, de Carvalho LR, Castiglia YM, Braz LG. Intraoperative and anesthesia-related cardiac arrest and its mortality in older patients: a 15-year survey in a tertiary teaching hospital. PloS one 2014; 9(8): e104041.

4. Cooper JB, Gaba D. No myth: anesthesia is a model for addressing patient safety. The Journal of the American Society of Anesthesiologists 2002; 97(6): 1335-1337.

5. Newland MC, Ellis SJ, Lydiatt CA, Peters KR, Tinker JH, Romberger DJ, et al. Anestheticrelated cardiac arrest and its mortality: a report covering 72,959 anesthetics over 10 years from a US teaching hospital. Anesthesiology 2002; 97(1): 108-115.

6. Prin M, Pan S, Phelps J, Phiri G, Li G, Charles A. Intraoperative mortality in Malawi. Anesthesia \& Analgesia 2019; 128(6): 1286-1291.

7. Arbous MS, Grobbee D, Van Kleef J, De Lange J, Spoormans H, Touw P, et al. Mortality associated with anaesthesia: a qualitative analysis to identify risk factors. Anaesthesia 2001; 56(12): 1141-1153.

8. Braz LG, Braz DG, Cruz DSd, Fernandes LA, Módolo NSP, Braz JRC. Mortality in anesthesia: a systematic review. Clinics 2009; 64(10): 999-1006.

9. Bainbridge D, Martin J, Arango M, Cheng D, Group E-bP-oCOR. Perioperative and anaesthetic-related mortality in developed and developing countries: a systematic review and meta-analysis. The Lancet 2012; 380(9847): 10751081.

10. Olsson G, Hallen B. Cardiac arrest during anaesthesia. A computeraided study in 250543 anaesthetics. Acta anaesthesiologica scandinavica 1988; 32(8): 653-664.

11. Pottecher T, Tiret L, Desmonts J, Hatton F, Bilaine J, Otteni J. Cardiac arrest related to anaesthesia: a prospective survey in France (19781982). European journal of anaesthesiology 1984; 1(4): 305-318.

12. Lienhart A, Auroy Y, Pequignot F, Benhamou D, Warszawski J, Bovet M, et al. Survey of anesthesia-related mortality in France. The Journal of the American Society of Anesthesiologists 2006; 105(6): 1087-1097.

13. Tuchinda L, Sukchareon I, Kusumaphanyo C, Suratsunya T, Hintong T, Thienthong S. The Thai

Van Tip Derg Cilt:28, Say1:2, Nisan/2021 
Anesthesia Incident Monitoring Study (Thai AIMS): an analysis of perioperative complication in geriatric patients. J Med Assoc Thai 2010; 93(6): 698-707.

14. Sprung J, Warner ME, Contreras MG, Schroeder DR, Beighley CM, Wilson GA, et al. Predictors of Survival following Cardiac Arrest in Patients Undergoing Noncardiac SurgeryA Study of 518,294 Patients at a Tertiary Referral Center. Anesthesiology: The Journal of the American Society of Anesthesiologists 2003; 99(2): 259-269.

15. Nanji KC, Patel A, Shaikh S, Seger DL, Bates DW. Evaluation of perioperative medication errors and adverse drug events. The Journal of the American Society of Anesthesiologists 2016; 124(1): 25-34.

16. Arulkumaran N, Corredor C, Hamilton M, Ball J, Grounds R, Rhodes A, et al. Cardiac complications associated with goal-directed therapy in high-risk surgical patients: a metaanalysis. British journal of anaesthesia 2014; 112(4): 648-659.

17. Rooke GA. Cardiovascular aging and anesthetic implications. Journal of cardiothoracic and vascular anesthesia 2003; 17(4): 512-523. 